\title{
The Principle of 'Self-Control' in the Design of Instruments, Processes and Procedures: True Success Factors of Talent Management
}

\author{
Jens Landwehr \\ Faculty of Management, Economics and Social Sciences, Seminar of Personnel Economics and HRM, University of Cologne, Cologne, \\ Germany \\ Email address: \\ Jenslandwehr@me.com \\ To cite this article: \\ Jens Landwehr. The Principle of 'Self-Control' in the Design of Instruments, Processes and Procedures: True Success Factors of Talent \\ Management. Journal of Human Resource Management. Vol. 4, No. 6, 2016, pp. 65-76. doi: 10.11648/j.jhrm.20160406.11
}

Received: October 31, 2016; Accepted: November 18, 2016; Published: December 21, 2016

\begin{abstract}
There seems to be a lack of clarity both in research and practice as to what makes talent management instruments and processes truly successful. This study shows, HR organizations and talent managers in many German organizations prefer more traditional over innovative procedures and instruments, even if latter instruments are empirically linked to more success as shown by our research. Furthermore, this paper makes a contribution to the question what makes talent management processes, procedures and instruments truly more successful than others. Based on the responses of 125 participants of an online survey-talent managers and other HR professionals responsible for talent management-we linked the success of certain talent management instruments to specific ingredients which appear to be the differentiators of successful talent instruments and procedures. We found that what we label 'organization centric' talent management instruments driven by the language of corporate requirements and personnel needs often lead to lower levels of talent management success. On the other hand, 'employee centric' talent management instruments and processes, which take an employee's self-efficacy, initiative, skills, and personality as starting point resulting in what we call a 'pull dynamic' of employee engagement, are significantly more associated with perceived talent management success. We also found that these instruments tend to be associated with lower levels of fluctuation and external recruiting rates. Furthermore, we found that the professionalization of talent management has a positive effect on the relationship described. The study results have important implications on the design, activities and branding of talent management in organizations.
\end{abstract}

Keywords: Talent Management, Success Factors, Pull Dynamic, Push Dynamic, Self-Control, Self-Management, Employee Centric, Organization Centric

\section{Introduction}

Talent management in organizations, which in its current form ignited in 1997 with a McKinsey study on the assumed future talent shortage, implies a paradox: While a talent is 'given' to an individual, which requires special development and fostering, management summarizes a set of professional activities related to coordinate a group of people to achieve a common goal. While the development of talent is highly personal, the management process is often an impersonal, top-down process which is oriented around corporate and market requirements. The French revolution brought the rise of the individual and the emphasis of personal talents, which in turn-a hundred years later-the Industrial Revolution denied so many early factory workers who were destined to adjust to the pace of machines. The battle of personal versus organizational control continued through the ages with early rights granted by the state (Rousseau 1762), fueled after WWII with new insights about people's motivations (Herzberg. 1959; McGregor, 1960) and continuing with unprecedented levels of participation in our current internet age (Tirole, 2010). However, while the internet allows more freedom than ever before, only compromised by the freedom of others and social media regulation, employees are asked to follow more and more defined and precise organizational strategies which they can barely influence or even 
understand. The paradox peaked in 2009 with the start of the economic crisis, when many companies had to balance on ongoing shortage of top talents while managing their talent surplus (Moser, Saxer, 2008). Balancing these paradigms is not easy for most organizations. Talent management processes in organizations need to carefully manage the paradoxical goal of freedom versus control to enable a maximum level of accomplishment and to meet organizational requirements.

Previous research revealed a pattern which sparked further analyses of the findings presented in this paper. It appeared that the success critical instruments and processes had in common an elevated level of active employee involvement in the talent management processes which are often dominated by HR. Also, it appeared that the success critical instruments and processes focused more on the applicant's strengths and possible contributions leaving more space to consider personal preferences and goals rather than organizational requirements. These findings let to the hypothesis that the construct of self-control could be an important success factor of talent management. At the same time, self-control appears as the more practical and economic approach to management in many relevant organizational contexts such security, learning, recruitment, engagement, and culture (Deloitte Human Capital Trends Study 2015).

This construct of self-control, defined here as employee centricity or pull dynamic, which represents the main independent variable, is the focus of this study and is outlined in more detail in the following section. Given the counterintuitive and irrational avoidance of the principle of self-control in the practice of talent management, it is of benefit to understand the reasons. Furthermore, it is the objective of this research to contribute to a practical integration of the concepts of self-control and self-efficacy into the talent management practice in German organizations and redesign its instruments and procedures accordingly.

\section{Related Works}

Since the beginnings, talent management has always been discussed controversially. The McKinsey report of 1997 originally fueled the perspective on talent management to focus the attention on the group of individuals who produce disproportionately high contributions to the company success. Much of the theory and practical advice of this line of thought focuses on how to define, identify and retain these individuals, which is often labeled the critical workforce (Lewis \& Heckman, 2006). For example, Collings \& Mellahi (2009) emphasize the links to strategic decision making and propose a model for measuring the effects of talent management on this group of people. On the other hand, Tarique and Schuler (2009) find that most of the previous research is based on limited information and has a number of theoretical deficiencies, thus leading to a critique of the critical workforce approach. Tervö (2009) further defines the market failure of the critical workforce approach and proposes how to measure its effects while Beechler and
Woodward (2009) claim that the McKinsey imposed strategic focus on A-Performers often backfires. The authors cite recent research (such as Groysberg et al 2004; Groysberg at al 2006; Groysberg et al 2008) supporting the pivotal role of context in determining individual and organizational performance (Beechler and Woodward, 2009). Pfeffer and Sutton's (2006) evidence based management approach also supports this critical view towards many talent management approaches finding that forced raking produces lower productivity. They especially critique the star focus in many talent management approaches and also find that there is a knowing-doing gap, which matches well our findings, and identify several distinct reasons for this gap. Since the critique of the McKinsey approach peaked, a third line of thought emerged with a focus on the global requirements of talent management and a focus on processes and instruments in use. Stahl (2007) focuses on the influence of context in a study of talent management processes and practices in a sample of 37 MNCs.

The insight that management should be motivational is also not new. As early as the 1940 s, cybernetics started to analyze human behavior in the context of decision, game and system theory based on the Macy Conferences of 1946-1953 on "Circular causal, and feedback mechanisms in biological and social systems" (Foerster 1953). The positive influence of self control was established by McGregor in his motivation theory (McGregor, 1960). In an organizational setting, McGregor (1960) differentiated between the poles of 'stress on direction and external control' and 'stress on integration and self control' following Herzberg's motivation theory (1958) without a clear preference for one or the other. Badura's concept of self-efficacy brings emphasis to individuals need for independence and association with the purpose of things. While the neoliberal decade of the 1980s has produced limited attempts to increase self control (Walton, 1985), more recently, economic theory has rediscovered the economics of social value orientation (Upton, 2009; Schmitt \& Dörfel, 1999; Van Lange et al, 1997; Van Lange 1999) thus being able to clearly describe the most desirable behavior in a corporate setting. Only since the arrival of social media and changing work preferences is there an established link to modern talent management processes (Hogan, Hogan, Kaiser, 2010).

On the contrary, there has been surprisingly little empirical research to identify success factors of talent management taking the social psychological concepts of the last 30 years into account. This is particularly surprising, as evidence both in research and practice increasingly indicates that talent management instruments as used in many organizations fail to deliver, and some even argue the more focus on talent management, the more damage is caused (Meifert, 2010; Knoblauch 2010; Moser, Saxer 2008). As an example, Pfeffer (2006) identified that 'Forced Ranking' led to lower productivity, inequity, damage to morale, and mistrust in leadership, however it is the guiding talent management principle in the majority of organizations. Martin and Schmidt (2010) found that talent management "too often 
focuses on management rather than talents, on evaluating past performance rather than enabling future performance and on complex top-down driven review processes rather than 360-degree enabled grids of performance measurements including self-assessments and how they match with actual performance" (Martin and Schmidt, 2010). In addition, several previous studies identified unclear objectives of talent management in many organizations which make it impossible to define quantitative success metrics (Capelli 2008).

However, a broad study to document the use of talent management instruments and to identify the success factors of talent management has never been done before. The research presented here responds to this gap and is based on a survey on the use of talent management instruments and processes in 125 German organizations conducted by the author in 2009. The study identified instruments and processes linked to success (as measured by the perception of talent managers), and found several common success factors. These included potential measurement, differentiation, the openness and transparency of processes, and the use of alternative career paths, among others. There was also the tendency that these instruments and processes are less commonly used in practice compared to other traditional instruments thus providing a plausible explanation why talent management fails so often in practice.

\section{Research Questions}

The aim of this investigation is to establish empirically the relationship between self-control and the success of talent management instruments and processes. We expect a positive relationship between success of talent management and instruments and self-control processes, which is defined by high levels of engagement and involvement by the employee rather than the HR department or supervisor. We further believe the success is based on what we call pull mechanism, which results in less friction between the employee and the organization and a more efficient way of negotiating common goals. We also expect that these instruments are less commonly practiced in German organizations than what we define as traditional organization centric instruments. We believe the reason for this irrational use of talent management instruments is insecurity about people development and behavior and a lack of clarity about the efficiencies that can be accomplished when applying the pull mechanism in talent management. For that reason we defined the equation such that it can help quantify the effects of good talent management practice. Thus, our research is guided by the following research questions and hypotheses:

Hypothesis 1a: Employee centric (self-control) talent management instruments and processes are positively correlated to the success of talent management (defined as assessment by talent managers), and negatively correlated to external recruiting rates and fluctuation.

Hypothesis 1b: Employee centric (self-control) talent management instruments and processes are characterized by a 'pull mechanism' leading to high employee involvement; as the pull mechanism defines employee centric talent management, it is responsible for its success. As a result, it leads to efficiencies in negotiating common goals between the employee and the organization.

Hypothesis 2: Employee centric (self-control) talent management instruments and processes are less common practice in German organizations compared to traditional organization centric talent management.

Hypothesis 3: Employee centric instruments are defined by self-efficacy and social value orientation but these concepts are consistently and systematically undermined in today's talent management practice

Hypothesis 4: The positive relationship between pull dynamic and success of talent management is stronger if a well defined infrastructure is in place.

\section{Methods}

\subsection{Sample}

A total of 125 participants responded to an online survey. The sample was drawn from German businesses with revenues larger than $€ 1$ billion, across all industries. Of the participants, one third identified themselves as talent managers, another third as other HR professionals and another third as personnel managers or general managers. The average size of the participating organizations was about 20,000 employees with all major industries being represented.

\subsection{Design and Procedure}

The invitation to participate was addressed to the Personnel Managers/departments by email. The broad purpose was explained to the participants combined with the incentive to receive the study results upon completion of the study as well as a free benchmarking against the other participants. In addition to demographic items, the survey contained measures for the success of talent management processes and procedures (H1), the use of employee centric instruments (H2), for the pull dynamic making employee centric measures more efficient (H3), and the changing roles in HR (H4).

\subsection{Measures}

\subsubsection{Success of Talent Management}

Participants were asked to assess the success of talent management in their organizations on a 5 item scale. Overall the success of talent management was rated as 4.01 with a standard deviation of 0.83 , indicating a very high interest in the topic.

\subsubsection{Self-Control (Employee Versus Organization Centricity; Pull Versus Push Dynamic)}

This study intends to empirically demonstrate the relationship between employee centric instruments and processes and procedures and the success of talent management. For that reason, employee centricity had to be defined normatively for all instruments and procedures. This was accomplished by 
assigning employee centricity levels (push or pull) to each instrument and process based on common (worldwide) talent management practice (Deloitte Human Capital Trends study 2014). In preparation of the second research step, each instrument as well as each process/procedure in use was defined as either push or pull. Furthermore it was asked which intervening variables could be identified which would influence the strength of the relationship between independent and dependent variable. This study has tried to systemize these arguments by defining a pull mechanism to talent management versus push mechanisms. The questions in the accompanying questionnaire try to reflect the following hypothesis and the pull versus push mechanisms. The authors were looking for a way to describe pull mechanisms in talent management. Push mechanism in talent management can be described as HR or manager initiated activities, as opposed to employee centered activities, i.e. what is being executed by the employee rather than the HR manager. The quantitative section of the study surveyed the use of instruments for the different target groups Top Managers, Middle Managers with or without personnel responsibility and all employees. Here it was assured that both pull and push instruments were being included in the study. In the qualitative section of the study it was questioned how these instruments were being used. All questions were assigned to a push versus a pull factor. Finally, the questionnaire includes questions related to the level of professionalization of the talent management infrastructure, such as ratio of talent professionals compared to number of white color workers and employees reviewed in panels etc. Self-control was defined as HR activities which are being initialized by the employee rather than HR or the manager. In recruiting, today active employees generally are being included in recruiting activities, i.e. as interviewers in recruiting interviews or as sparring partners at recruiting events such as fairs, with similar applications in the other HR processes.

\subsubsection{External Recruitment Rate / Fluctuation}

In order to test the validity of the talent managers perceived success of talent management, we were looking for additional objective success measure. This was the percentage of roles filled though external hires, as well as the fluctuation rates of people identified as talents, as well as the general fluctuation rate.

\subsubsection{Infrastructure / Role of HR}

Participants were asked to respond to different questions related to the infrastructure of talent management, roles of $\mathrm{HR}$, confidence in the talent management process, success measurements, IT tools available, as well as target groups of talent management. Responses were requested as percentages of confidence with which the processes and roles within the talent management process were executed.

\section{Results}

The mean, standard deviations and Cronbach's alpha to measure the internal consistency of the main variables used in the study are presented in table 1 . The data shows large differences in the use of specific instruments across all target groups. Generally, companies tend to apply more push instruments than pull instruments (conventional talent management), as shown by the means. The results also show that pull instruments across the different talent management areas (recruiting etc) correlate high, which is documented by high values for internal consistency.

In order to test the hypothesis about the significance of push vs. pull dynamic in talent management instruments, regression analyses were carried out with three different dependent variables: talent managers' assessment of talent management (table 2), external recruiting rate (table 3), and fluctuation (table 4). For each of these variables, separate regression analyses were carried out controlling for external factors (talent management infrastructure), company size and industry. For each of the three models, we initially controlled for instruments, size and industries (model a), the pull index (model b), the push index (model c) and for both (model d). In addition, separate hierarchical regression analyses were carried out for each facet of pull dynamic, as well as the pull index (tables 5 and 6).

The analysis for the assessment of talent management by the talent managers indicates that the main effect of employee centricity was significant in model $1 \mathrm{~b}(\beta=0.7398$; $\left.\mathrm{p}<0.000^{* * *}\right)$ and in model 1c $\left(\beta=0.7668 ; \mathrm{p}<0.000^{* * *}\right)$ controlling both for company size and industry. Thus, an increase in the score of pull index by one unit leads to an increase of the talent management evaluation by the study participants by $0.74(\mathrm{p}<0.000)$.

The analysis for the external recruiting rate (model 2), presented in table 3 , indicates that the main effect was directional as expected and significant in model $2 b$ only $(\beta=-$ $0.0773 ; \mathrm{p}<0.087 * *)$.

The analysis for fluctuation rate (model 3 ) presented in table 4 , indicates the main effect was directional as expected but not significant.

Tables 5 and 6 show the details of the push and pull index respectively, controlling for size and industry, showing the effect of each group of elements individually.

Table 5 shows that talent infrastructure, succession planning instruments as well as the statement 'Internal candidates previously not considered for the position can be successful' have a positively significant effect on talent success. In model $4 \mathrm{a}$ we control for size and industry and show the effect of each group of elements of pull index individually. In model $4 \mathrm{~b}$ we added the effect of the element 'personal goals'; in model 4c, of the element 'personnel development practice', and in model $4 \mathrm{~d}$, the element 'career paths'.

Table 6 shows that the element most strongly and negatively linked to talent management success, is the statement 'Often positions that are advertised internally will be filled with candidates who have been nominated before' which eludes to the advertisement process as being purely a formality which does not really represent what the company believes in. In model 6 a we control for size and industry and show the effect of each group of elements of push index individually. In model $6 \mathrm{~b}$ we added the effect of the element 'initiative' (by line reporting rather than the individual him or 
herself, and in model $6 \mathrm{c}$ we added the effect of the element 'Sabbatical as career handicap' demonstrating the overall clearly more negative effect of such statements and processes on the perceived success of talent management.

Table 1. Overview of main indices, variables and items.

\begin{tabular}{|c|c|c|c|c|}
\hline & Variable code & Mean & Standard deviation & Cronbach's Alpha \\
\hline Talent Infrastructure Index (Min=0; Max=1) & & & & $\alpha=0.70$ \\
\hline $\begin{array}{l}\text { - Does your company have a separate department dealing with talent } \\
\text { management? }\end{array}$ & Pos_tm & .8016529 & 400413 & \\
\hline - Does your company have a talent management strategy defined? & Strat_tm & .557377 & .4987452 & \\
\hline - Do you measure the results of talent management in your company? & Erfmes tm & .4545455 & .5 & \\
\hline - Is talent management supported by IT? & Itunt tm & .3801653 & .4874457 & \\
\hline - Do you use external benchmarking for talent management? & Exbench_tm & .1848739 & .3898367 & \\
\hline Recruiting Instruments (Pull); Min $=0 ;$ Max $=1$ & & & & $\alpha=0.79$ \\
\hline - Portal for internal candidates (bpi) & Bpi & .4327957 & .4142446 & \\
\hline - Portal for external candidates (bpe) & Bpe & .4798387 & .373944 & \\
\hline - Refer a friend program (raf) & Raf & .2096774 & .3542687 & \\
\hline - Automated communications with talent pools via emails/texting (ak) & $\mathrm{Ak}$ & .0483871 & .1736663 & \\
\hline - Structured exit management (sem) & Sem & .2016129 & .3676595 & \\
\hline Recruiting Instruments (Push); Min $=0 ;$ Max $=1$ & & & & $\alpha=0.70$ \\
\hline - Detailed job descriptions (ds) & Ds & .672043 & .3918406 & \\
\hline - Detailed qualifications catalogue (da) & $\mathrm{Da}$ & 6048387 & .4129059 & \\
\hline - Headhunting (aan) & Aam & .5026882 & .3194846 & \\
\hline - Assessment Center internal candidates (asi) & Asi & .3198925 & .3437379 & \\
\hline - Assessment Center external candidates (ase) & Ase & .3602151 & .3362925 & \\
\hline - Talent pools (tp) & $\mathrm{Tp}$ & .5215054 & .3759767 & \\
\hline - Personalized onboarding program (po) & Po & .3844086 & .4335612 & \\
\hline Performance Management Instruments (Pull); Min=0; Max=1 & & & & $\alpha=0.77$ \\
\hline - Target setting (zv) & $\mathrm{Zv}$ & .8172043 & .3190853 & \\
\hline - Performance evaluation in several dimensions/categories (lb) & $\mathrm{Lb}$ & .7768817 & .3649548 & \\
\hline - 360 degree feedback $\left(\mathrm{pm} \_360\right)$ & $\mathrm{Pm} \_360$ & .3198925 & .3489543 & \\
\hline Performance Management Instruments (Push); Min $=0 ;$ Max $=1$ & & & & $\alpha=0.71$ \\
\hline - Quantitative performance indicators (ql) & Q1 & 655914 & .3963143 & \\
\hline - Potential evaluations, structured and periodic (pb) & $\mathrm{Pb}$ & .6693548 & .3765866 & \\
\hline - Management panels for performance evaluations (mpl) & & .3870968 & .425873 & \\
\hline - Management panels for promotions (mpb) & $\mathrm{Mpb}$ & .2123656 & .3513676 & \\
\hline - Recommended distribution of performance categories (evl) & Evl & .2473118 & .3984409 & \\
\hline - Forced distribution (fd) & $\mathrm{Fd}$ & .0564516 & 2113397 & \\
\hline Compensation Management Instruments (Pull); Min $=0 ; \operatorname{Max}=1$ & & & & $\alpha=0.75$ \\
\hline - Variable pay components in general (vgka) & Vgka & .7741936 & .3361625 & \\
\hline - Variable pay components on the basis of team performance (vgkt) & Vgkt & .3682796 & .3960477 & \\
\hline - Variable pay components on the basis of individual performance (vgki) & Vgki & .6827957 & .3750455 & \\
\hline - Optional unpaid vacation sabbatical (uu) & $\mathrm{Uu}$ & .2553763 & .3967093 & \\
\hline Compensation Management Instruments (Push); Min=0; Max=1 & & & & n.a. \\
\hline - Variable benefits (vzl) & Vzl & .2284946 & .3690045 & \\
\hline - Variable pay components on the basis of company performance (vgku) & Vgku & 6827957 & .3701969 & \\
\hline Skill and Competency Instruments (Pull); Min= $0 ;$ Max $=1$ & & & & $\alpha=0,62$ \\
\hline - Personalized development plans (pep) & Pep & .6129032 & .4085515 & \\
\hline - Employee portal for training and continuing education (mp) & $\mathrm{Mp}$ & .5322581 & .4576349 & \\
\hline Skill and Competency Instruments (Push); Min=0; Max=1 & & & & $\alpha=0.65$ \\
\hline - Competency model $(\mathrm{km})$ & $\mathrm{Km}$ & .6155914 & .4121996 & \\
\hline - Management training, external (mt) & Mt & .6424731 & .3213943 & \\
\hline Succession Planning Instruments (Pull); Min $=0 ; \mathrm{Max}=1$ & & & & \\
\hline - Probability assessment for turnover rates (ba) & $\mathrm{Ba}$ & .2419355 & .3539395 & \\
\hline - Personalized career paths (pl) & $\mathrm{pl}$ & 2043011 & .3284457 & \\
\hline - Alternative career paths (aak) & Aak & .3037634 & .355654 & \\
\hline Succession Planning Instruments (Push); Min $=0 ;$ Max $=1$ & & & & $\alpha=0.85$ \\
\hline - Mid and long term succession plans (mnlp) & Mnlp & .5430108 & .3332459 & \\
\hline - Domino lists (dl) & $\mathrm{Dl}$ & .1129032 & .2546305 & \\
\hline - Requirements / potential alignments (abp) & $\mathrm{Abp}$ & .3145161 & .4016732 & \\
\hline Pull Index $(M i n=1 ; M a x=5)$ & & & & $\alpha=0.71$ \\
\hline - There is a high number of internal applications for vacancies & Stelbes_4 & 3.141509 & .9898406 & \\
\hline $\begin{array}{l}\text { - Frequently, internal candidates that have not been considered for this role } \\
\text { are more successful }\end{array}$ & Stelbes_6 & 2.783019 & .8508228 & \\
\hline $\begin{array}{l}\text { - The job requisition for job vacancies is oriented on the capabilities of } \\
\text { internal candidates }\end{array}$ & Stelbes_8 & 2.669811 & 1.002109 & \\
\hline $\begin{array}{l}\text { - The employees' personal objectives are strongly considered for their } \\
\text { career development }\end{array}$ & Berueck_2 & 3.682243 & .7721342 & \\
\hline - The personal living condition is considered for labor time and task & Berueck 4 & 3.27619 & .7531375 & \\
\hline
\end{tabular}




\begin{tabular}{|c|c|c|c|c|}
\hline & Variable code & Mean & Standard deviation & Cronbach's Alpha \\
\hline \multicolumn{5}{|l|}{ responsibilities } \\
\hline - The career development plans reflect the realistic professional objectives & Sukman_1 & 3.602041 & .74252 & \\
\hline $\begin{array}{l}\text { - Training and advanced training plans are seen as self-controllable by our } \\
\text { employees }\end{array}$ & Sukman_2 & 3.336735 & .8727711 & \\
\hline $\begin{array}{l}\text { - Our Skill and Competency Management considers the employees' } \\
\text { personality }\end{array}$ & Sukman_3 & 3.520408 & .9441037 & \\
\hline $\begin{array}{l}\text { - The company permits individual career paths that are oriented on the } \\
\text { employees' interest and objectives in life }\end{array}$ & Nukman_1 & 3.04902 & 1.137806 & \\
\hline Push Index-items still in discussion $(\mathrm{Min}=1 ; \mathrm{Max}=5)$ & & & & $\alpha=0.85$ \\
\hline $\begin{array}{l}\text { - Working experience is a critical factor for filling managing positions in } \\
\text { our company }\end{array}$ & Stelbes_3 & 3.648148 & .7771842 & \\
\hline $\begin{array}{l}\text { - Internal jobs are frequently filled with people who have been informally } \\
\text { appointed to that position }\end{array}$ & Stelbes_5 & 3.168224 & 1.032363 & \\
\hline $\begin{array}{l}\text { - Cross-division or functional career paths are more often initiated through } \\
\text { the employer than individual employees }\end{array}$ & Initfuwe & 3.273585 & 1.046837 & \\
\hline $\begin{array}{l}\text { - Global mobility assignments are more often initiated through the } \\
\text { employer than individual employees }\end{array}$ & Initausent & 2.095745 & .951164 & \\
\hline $\begin{array}{l}\text { - Personnel development plans are more often managed through the } \\
\text { employer than individual employees }\end{array}$ & Einfent_dv & 4 & .6963106 & \\
\hline $\begin{array}{l}\text { - The use of flexible time-off policy obstructs a structured succession } \\
\text { management }\end{array}$ & Nukman_3 & 2.535354 & 1.081506 & \\
\hline
\end{tabular}

Table 2. Results of regression analysis-effects on talent management success.

\begin{tabular}{|c|c|c|c|c|c|c|c|c|}
\hline & Model 1a & & Model 1b & & Model 1c & & Model 1d & \\
\hline & Beta & $\mathbf{P}$ & Beta & $\mathbf{P}$ & Beta & $\mathbf{P}$ & Beta & $\mathbf{P}$ \\
\hline Talent Infrastructure & .9216317 & $0.002 * * *$ & .8025046 & $0.005 * * *$ & .8532003 & $0.004 * * *$ & .7884271 & $0.005 * * *$ \\
\hline Recruiting Instruments & -.1137533 & 0.819 & .2389419 & 0.598 & -.0706301 & 0.885 & .27715 & 0.537 \\
\hline Performance Instruments & .2253155 & 0.558 & .2383817 & 0.535 & .4058387 & 0.306 & .2327774 & 0.541 \\
\hline Compensation Instruments & .3399176 & 0.354 & .2500259 & 0.522 & .3910555 & 0.279 & .2168241 & 0.537 \\
\hline Skill / Competency Instruments & -.3658126 & 0.286 & -.5099467 & 0.113 & -.2618647 & 0.439 & -.4725596 & 0.138 \\
\hline Succession Instruments & 1.314862 & $0.003 * * *$ & .5244686 & 0.205 & 1.372207 & $0.002 * * *$ & .5924037 & 0.151 \\
\hline Size Dummy 2 & -.1313237 & 0.532 & .0264563 & 0.890 & -.1577851 & 0.679 & -.0369896 & 0.848 \\
\hline Size Dummy 3 & .4180672 & 0.149 & .5605769 & $0.041 * *$ & .4482604 & 0.262 & .5413379 & 0.046 \\
\hline Size Dummy 4 & .0133035 & 0.963 & -.028918 & 0.909 & -.0881289 & 0.828 & -.1114369 & 0.665 \\
\hline Industry Dummy 1 & .4441935 & 0.326 & .1619212 & 0.742 & .3526485 & 0.420 & .168069 & 0.730 \\
\hline Industry Dummy 2 & .4698682 & 0.305 & .2493629 & 0.622 & .4888292 & 0.671 & .3037066 & 0.545 \\
\hline Industry Dummy 3 & .5652261 & 0.240 & .3726218 & 0.468 & .5956076 & 0.367 & .4091617 & 0.421 \\
\hline Industry Dummy 4 & .7780957 & $0.083 * *$ & .424756 & 0.384 & .795179 & 0.311 & .4569336 & 0.345 \\
\hline Push Index* & & & & & -.1149495 & 0.117 & -.1072621 & 0.120 \\
\hline
\end{tabular}

Legend: $\mathrm{P}<0,001:^{* * *} ; \mathrm{p}<0,05:^{* *} ; \mathrm{p}<0,1:^{*}$

Table 3. Results of regression analysis-effects on external recruiting rate.

\begin{tabular}{|c|c|c|c|c|c|c|c|c|}
\hline & Model 2a & & Model 2b & & Model 2c & & Model 2d & \\
\hline & Beta & $\mathbf{P}$ & Beta & $\mathbf{p}$ & Beta & $\mathbf{P}$ & Beta & $\mathbf{p}$ \\
\hline Talent Infrastructure & -.0235182 & 0.784 & -.0115809 & 0.900 & -.0582712 & 0.510 & -.0325851 & 0.733 \\
\hline Recruiting Instruments & .0101972 & 0.946 & -.0284113 & 0.858 & .0679654 & 0.592 & -.0647066 & 0.693 \\
\hline Performance Instruments & .1056304 & 0.387 & .1115246 & 0.402 & .0520585 & 0.752 & .1267968 & 0.380 \\
\hline Compensation Instruments & .1056304 & 0.132 & -.0892668 & 0.451 & .0581371 & 0.554 & -.0930451 & 0.461 \\
\hline Skill / Competency Instruments & .018848 & 0.850 & .0657053 & 0.550 & .2201341 & 0.028 & .0910498 & 0.438 \\
\hline Succession instruments & -.0641029 & 0.609 & .018545 & 0.894 & -.0802975 & 0.454 & .0049467 & 0.973 \\
\hline Size Dummy 2 & .203044 & 0.001 & .1880641 & 0.003 & .2044722 & 0.001 & .1741328 & 0.008 \\
\hline Size Dummy 3 & .0272689 & 0.748 & .0420787 & 0.642 & .0747343 & 0.390 & .0814265 & 0.416 \\
\hline Size Dummy 4 & .0586827 & 0.488 & .0354243 & 0.679 & .0214957 & 0.792 & .0278538 & 0.752 \\
\hline Industry Dummy 1 & .0042543 & 0.962 & .0215269 & 0.844 & -.0586804 & 0.552 & .0178821 & 0.874 \\
\hline Industry Dummy 2 & -.0456068 & 0.610 & .0006099 & 0.995 & -.0652945 & 0.511 & .0021494 & 0.985 \\
\hline Industry Dummy 3 & .0105566 & 0.918 & .0247735 & 0.840 & -.0554736 & 0.618 & .0274779 & 0.824 \\
\hline Industry Dummy 4 & -.0206783 & 0.811 & .0229299 & 0.827 & -.0367637 & 0.701 & .0240485 & 0.822 \\
\hline Push Index* & & & & & .0234014 & 0.721 & -.0024371 & 0.975 \\
\hline
\end{tabular}

Legend: $\mathrm{P}<0,001:^{* * *} ; \mathrm{p}<0,05:^{* *} ; \mathrm{p}<0,1:^{*}$ 
Table 4. Results of regression analysis-effects on employee turnover.

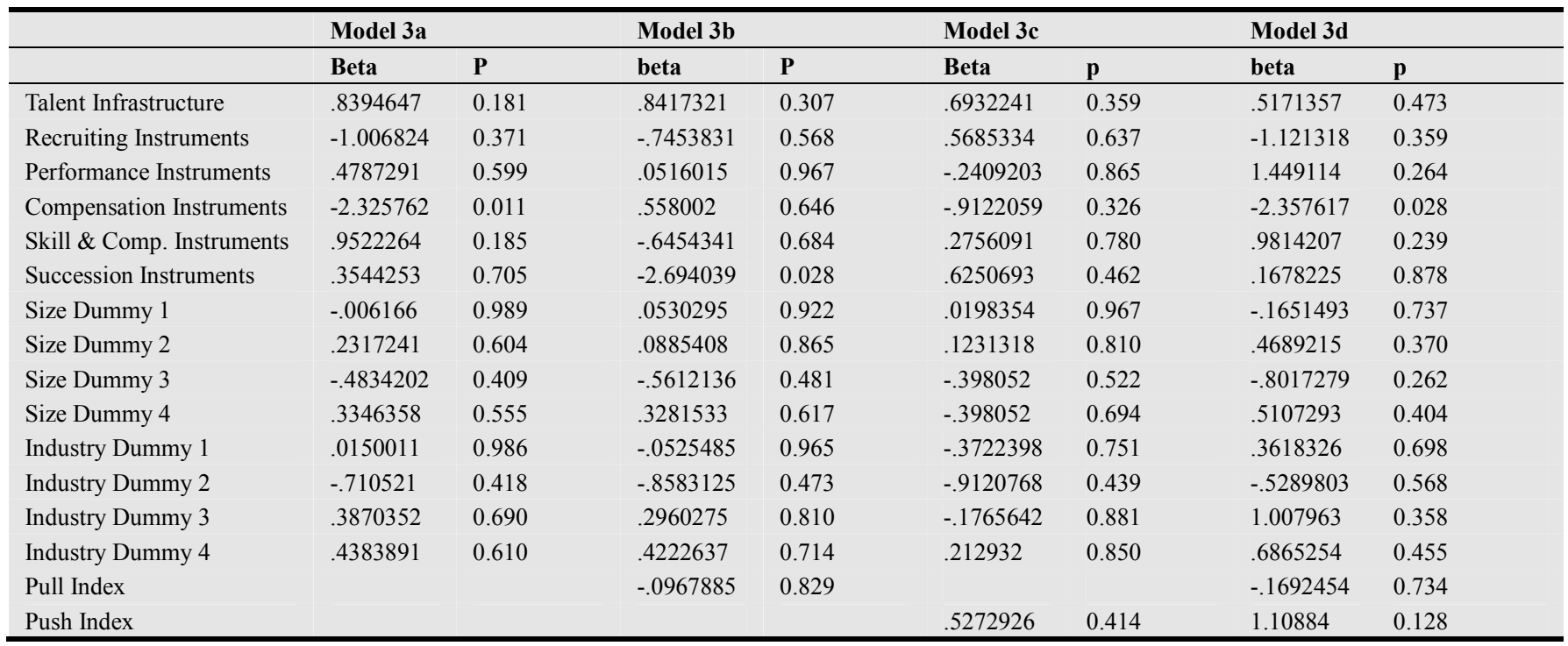

Legend: $\mathrm{P}<0,001: * * * ; \mathrm{p}<0,05: * * ; \mathrm{p}<0,1: *$

Comment:

Model a=Dummy variables, Infrastructure, Instruments

Model $b=$ Dummy variables, Infrastructure, Instruments, Pull index

Model c=Dummy variables, Infrastructure, Instruments, Push index

Model d=Dummy variables, Infrastructure, Instruments, Pull index, Push index

Table 5. Results of regression analysis-effects of Pull index details on talent management success.

\begin{tabular}{|c|c|c|c|c|c|c|c|c|}
\hline \multirow[t]{2}{*}{ Details Pull index } & \multicolumn{2}{|l|}{ Model 4a } & \multicolumn{2}{|l|}{ Model 4b } & \multicolumn{2}{|l|}{ Model 4c } & \multicolumn{2}{|l|}{ Model 4d } \\
\hline & Beta & $\mathbf{P}$ & beta & $\mathbf{P}$ & beta & $\mathbf{p}$ & beta & $\mathbf{P}$ \\
\hline Talent Infrastructure & .7641181 & 0.010 & .699802 & 0.017 & .7907339 & 0.009 & .7230906 & 0.016 \\
\hline Recruiting Instruments & -.1070909 & 0.825 & -.028648 & 0.951 & .1042582 & 0.832 & .2513546 & 0.611 \\
\hline Performance Instruments & .3703277 & 0.359 & .1977903 & 0.623 & .1104652 & 0.790 & .2884523 & 0.490 \\
\hline Compensation Instruments & .2650902 & 0.465 & .4225106 & 0.245 & .5669181 & 0.122 & .2571193 & 0.508 \\
\hline Skill \& Comp. Instruments & -.268207 & 0.426 & -.2852836 & 0.385 & -.8305869 & 0.025 & -.768191 & 0.038 \\
\hline Succession Instruments & .9426603 & 0.039 & & 0.045 & .7752509 & 0.082 & .6493711 & 0.154 \\
\hline Size Dummy 2 & .0156739 & 0.940 & .0118497 & 0.953 & -.0811862 & 0.694 & -.0245264 & 0.905 \\
\hline Size Dummy 3 & .4711321 & 0.109 & .5244538 & 0.070 & .6743873 & 0.027 & 6158789 & 0.043 \\
\hline Size Dummy 4 & .0382608 & 0.891 & -.0967093 & 0.725 & -.0947538 & 0.723 & -.014827 & 0.955 \\
\hline Industry Dummy 1 & -.1478492 & 0.785 & .0248308 & 0.963 & .3224744 & 0.539 & .2685678 & 0.603 \\
\hline Industry Dummy 2 & -.0252538 & 0.963 & .2911908 & 0.594 & .615344 & 0.261 & .3257822 & 0.557 \\
\hline Industry Dummy 3 & .0123615 & 0.982 & .2203789 & 0.689 & .6039115 & 0.272 & .3832997 & 0.486 \\
\hline Industry Dummy 4 & .2222496 & 0.679 & .470319 & 0.375 & .6600415 & 0.208 & .5190406 & 0.317 \\
\hline Stelbes_6 (internal cand.) & .1818336 & $0.053 *$ & .154953 & $0.091 *$ & .0648085 & 0.495 & .0581827 & 0.536 \\
\hline Stelbes_8 (capabilities) & .1189128 & 0.135 & .0897608 & 0.263 & .0633595 & 0.423 & .0442413 & 0.574 \\
\hline Personal goals & & & & & & & & \\
\hline Berueck_2 (personal obj.) & & & .2416586 & $0.025^{*}$ & .0885446 & 0.446 & .0963715 & 0.401 \\
\hline $\begin{array}{l}\text { Berueck_4 (living } \\
\text { situation) }\end{array}$ & & & .0883144 & 0.413 & .0019574 & 0.986 & -.1047935 & 0.388 \\
\hline Personnel development & & & & & & & & \\
\hline Sukman_1 (career plans) & & & & & .3004558 & 0.013 & .2107334 & 0.095 \\
\hline Sukman_2 (training plans) & & & & & .1651214 & 0.103 & .1477403 & 0.142 \\
\hline Sukman_3 (personality) & & & & & .0951095 & 0.273 & .1261973 & 0.156 \\
\hline Career paths & & & & & & & & \\
\hline Nukman_1 (interests) & & & & & & & .1524793 & 0.098 \\
\hline
\end{tabular}

Legend: $\mathrm{P}<0,001: * * * ; \mathrm{p}<0,05: * * ; \mathrm{p}<0,1:^{*}$

Comment:

Model a=Dummy variables, Infrastructure, Instruments, Internal recruiting

Model $b=$ Dummy variables, Infrastructure, Instruments, Internal recruiting, personal goals

Model c=Dummy variables, Infrastructure, Instruments, Internal recruiting, personal goals, personnel development

Model d=Dummy variables, Infrastructure, Instruments, Internal recruiting, personal goals, personnel development, career üaths 
Table 6. Results of regression analysis-effects of Push index details on talent management success.

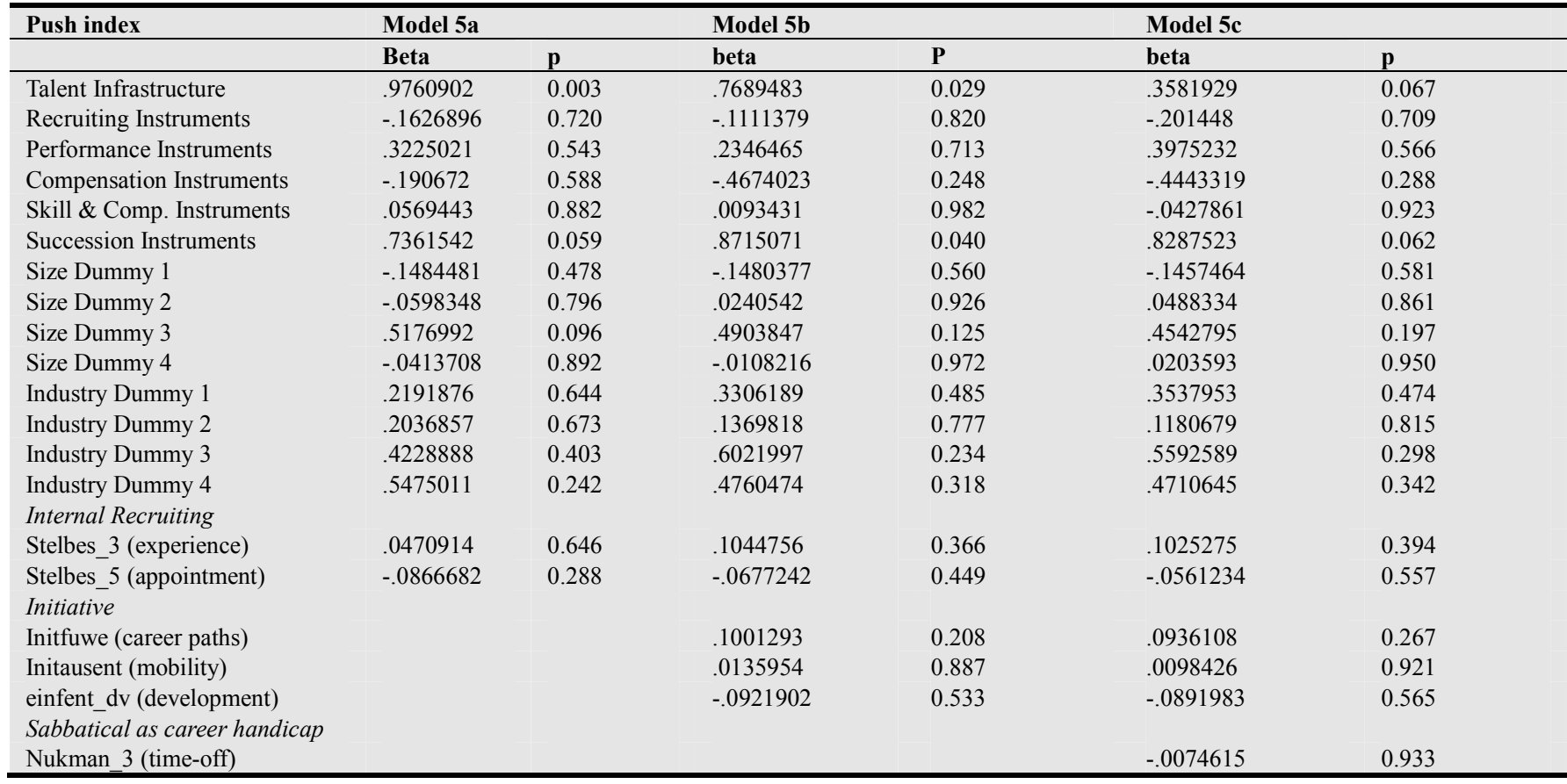

Legend: $\mathrm{P}<0,001: * * * ; \mathrm{p}<0,05: * * ; \mathrm{p}<0,1:^{*}$

Comment:

Model a=Dummy variables, Infrastructure, Instruments; Internal recruiting

Model $b=$ Dummy variables, Infrastructure, Instruments, Internal recruiting, Initiative

Model c=Dummy variables, Infrastructure, Instruments, Internal recruiting, Initiative, Sabbatical as handicap

\section{Discussion}

The key finding presented in this paper is that employee centric talent management instruments and processes are more successful than talent instruments which are purely oriented around organizational requirements. Employee centricity acknowledges and better embraces existing employee talents (rather than organizational requirements) and involves current employees more often in the execution of talent management processes (rather than HR). Surprisingly, talent elements with pull character are less commonly used despite the fact that they are more successful. Given the previous research on motivation, rewards and equilibrium theory, it is surprising that this is the case. This study is the first to have shown measurable effects linked to the choice of talent management instruments and processes.

While the positive relationship between self-control and the various success criteria are intuitive and based on motivation theory (Herzberg, 1060; McGregor 1960), thus far there has been a lack in empirical evidence to show so in organizations. Our findings support the case for the economies of self- management recently claimed by Tirole (2010): The pull factor associated with employee centric talent management instruments not only leads to less friction to negotiate common goals, but also to lower turnover and less external recruitment, thus emphasizing the economic and business value of employee centric talent management. Our results therefore not only support the motivational, but also the economic argument of self-control. While fairness and transparency as well as direct employee involvement in talent management processes and procedures directly lead to higher talent management success, it also saves the company significant recruiting cost. The clearer this evidence, the more it is surprising, that talent managers appear to be hesitant to implement these principles. They may feel that self-control undermines the strategic authority of the shareholders or senior management as these groups may have less control over strategy execution. However, the opposite seems to be the case. The results indicate that less control improves internal job mobility and reduces costly fluctuation. The economic value of self-control may therefore be enormous.

\subsection{Further Empirical Evidence for Self-Control as Success Factor}

Overall, our results confirm the scattered empirical examples describing the success of self-control mechanisms such as self-nomination processes. For example, a study from 2009 found that where self-nomination processes are combined with sophisticated assessment and selection tools, they have produced a more diverse pool of highly qualified talent in companies (Stage/Houghton 2009). Processes include, for example, a three-step nomination and selection process for the enterprise-level program including 360degree-type performance assessments; online testing of potential that measures foundational capabilities and predispositions as well as accelerators in order to assign a 
norm-based percentile standing; and an assessment center with simulations for gauging readiness for senior leadership roles Stage/Houghton 2009). In another study with US military personnel, Patton (2009) found that those selected as 'Aspire' participants, a special talent program, performed better. These individuals were afforded a range of activities, geared to individual and organizational needs, including training/education, on-the-job and business-driven development, and relationship-driven development. In addition, these individuals could apply to positions in military organizational management as a self-nomination process for joint service qualification (Patton 2009).

However, increased employee participation does not seem to automatically result in a healthy work environment (Busck, Knudsen, Lind 2010). While most of the literature points to a positive connection (Karasek, Theorell 1990), more recent research into psychosocial work environment problems questions their model's assumption of high job control compensating for high job demands (Stage/Houghton 2009). They conclude that there are limitations to the demand-control model in modern working life given the contextual changes in the employer-employee relationship. They show that while self-control by itself is not a factor to improve performance, it is a strong supporting factor when combined with intrinsic motivation, moderate scores on performance avoidance together with the ability to remain motivated and effectively regulate and control task behavior (Stage/Houghton 2009). These studies conclude that selfregulatory skills should be trained in order to have intrinsically motivated students perform well on novel tasks in the classroom (Van Nuland, Hanke, 2010)

\subsection{Measuring Efficiencies Through Pull Versus Push Dynamic}

HR is not the only discipline which tries to improve performance by giving up control and opening internal processes to external influences. Other examples are supply chain management, knowledge management and innovation, which all found that efficiencies can be generated by opening up corporate boundaries and mixing up traditional role and power concepts. All these areas have in common that control is being shifted from the organization towards the outside, generating a pull mechanism which builds on self-motivation with the result of increasing efficiencies.

Our results follow the AMO framework, which has become one of the dominant theoretical approaches toward exploring performance in the context of HR (Boslie et al., 2005; Boxall \& Purcell, 2008), and which shall serve us to express the effect of pull versus push on performance in a talent management context. According to the AMO framework, performance $(\mathrm{P})$ is a function of the employee's ability (A), motivation (M), opportunity $(\mathrm{O})$ to perform, to which we add $\mu$, the Pull effect, and $y$, Push effect, of talent management.

This following equation expresses the expected efficiencies through pull:

$$
\mathrm{P}=\mathrm{f}(\mathrm{A}, \mathrm{M}, \mathrm{O})+\mu-\mathrm{y}
$$

The equation reflects the fact that although the exact relationship between the variables has not been established, we do know that all variables impact employee performance (Boxall \& Purcell 2008). Furthermore, our formula extension $\mu-y$ expresses that all three effects are increased by the pull and decreased by push dynamic associated with talent management processes. Other factors determining the value of $\mu$ and $y$ are population-specific, in that new generations of employees demand more pull dynamic in HR processes. While there is culturally a predisposition in certain countries/cultures as well as professions for push versus pull, the global demands of the workforce in complex, dynamic, highly competitive and extremely volatile settings prevail. Therefore, pull has become part of employer branding (Tarique/Schuler 2010). Related processes are characterized by respect and win-win communications and therefore compatible with diversity and other social requirements.

\subsection{Current Practice and Thinking Often Contradicts Evidence}

Our study results highlight an interesting paradox. Pushtype talent management instruments seem to be more commonly used in practice. Despite its success and therefore surprisingly, HR professionals still seem to be reluctant to implement elements of self-control. HR in German organizations still does not seem to have the standing to introduce shifts in paradigms or even introduce innovative measures. So why is it that German organizations still largely rely on the push rather than pull mechanism? HR, due to its traditional administrative role, often doesn't seem to be in a position to initiate cultural shifts in organizations, and selfcontrol continues to be seen as counterproductive or inefficient, and its management appears difficult.

However, there appear to be other factors preventing HR, talent management as well as line managers from applying more self-control processes, despite the fact that they appear to be more effective and efficient than traditional pull models.

Provided the strength of the McKinsey line of thinking, this is not surprising. It appears, talent managers often don't know that talent management practice is counterproductive, and, they are often forced by line management to execute against their convictions. The reasons are often deeply rooted in the origins of the war for talent claimed by McKinsey and the resulting emphasize on critical workforce segmentation including the strategic value of roles and positions. As the value is entirely defined by the requirements of the organization, this way of defining talent management supports entirely the push elements of talent processes. This line of thinking points to an interesting interaction between the executive level and HR. The executive does not seem to trust HR to make fundamental decisions on power relationships or governance. While these are traditional HR tasks, the existential character may just be too large for HR (Ulrich 2007). 
Other reasons can be found at the organizational and individual levels. For example, HR is often still seen as a service rather than a strategic function and as such is conservative in the choice of its tools and methods. HR professionals are often not educated or experienced to apply modern motivation techniques and have anxiety with character and personality ratings (Smith et al, 2000; Bernardin et al 2000).

While our findings echo the lack of clarity around talent management claimed by Lewis \& Heckman, 2006 as well as Collings \& Mellahi (2009), we oppose their views in several important ways. The perspective of these authors, which we label 'normative' is linked most directly to the inception of the term talent management by a group of McKinsey consultants in 1997 and the resulting interest both in theory and practice. These authors (Collings \& Mellahi, 2009) often lament lack of clarity, and thus emphasize the definition of the critical workforce in organizations (Lewis \& Heckman, 2006). In addition, Collings \& Mellahi (2009) -as most of the relevant literature- define the requirements of the organization as starting point and motivation, organizational commitment and extra role behavior as desired outcomes of talent management.

However, our study results point to a different direction. Our study results would support a talent pool recruiting strategy, which means A-grade individuals are hired even though a clear position is not available, and make it their task to define the organizational requirements in question. This element of the 'normative' line of thinking is aligned with our survey results and the pull mechanism, as we find available talent should be driving who is hired and what needs to be done rather than following existing corporate requirements.

In addition, our findings support the 'critical' line of thinking about talent management as expressed by authors such as Pfeffer \& Sutton (2006) and Beechler \& Woodward (2009). These authors are grounded in the large societal changes such as the mixing of professional and life changes Potter (2005). Their main argument is that context determines a larger part of performance, and that talent management should focus more on talent development rather than selection and talent pools. This is in direct alignment with our findings that for example, the personalization of career paths seems to be most strongly linked to the success of talent management. In this context, the practice of forced raking seems to be the extreme example which authors such as Pfeffer (2009) blame for why talent management often doesn't work.

At the same time we support a pragmatic approach to talent management which emerged during a time of continued strong interest in the field academically and increased pressure to find practical talent management solutions. This research suggests that companies which excel at talent management ensure internal consistency and reinforce the practices they employ to attract, select, develop, evaluate and retain talent as well as closely aligning those practices with the corporate culture, business strategy and long term organizational goals (Stahl et al 2007). He continues that an engagement-friendly culture values the diversity employees bring to the table, respects individual needs, and inspires all employees to pursue a common and exciting vision of the future. Finally, our research also supports Arthur (1994), suggesting that organizational effectiveness can be enhanced by career movements across organizational boundaries, and Capelli (2008), who draws insights from supply chain management.

The question is how far self-control processes can be effective before self-regulation becomes suboptimal (Luhmann 1984). According to system theory, checks and balances can be designed to manage distortions caused by the pull dynamic. Another potential implication of this result may be to define the boundaries of self-control. The question is how far can this go and to which degree the success factors of talent management compromise the traditional organizational power structure.

\subsection{Communication and Infrastructure Are Key in Helping to Balance Self Control}

The lack of communication in an organizational setting has long been lamented (Clutterbuck 2010), and more generally, communications between the individual and the organization need to be improved to make better use of people in organizations (Leigh 2009). This is even more so true when self-control processes are being applied more broadly in organizations. However, communication on potential and development topics is always sensitive and needs to be organized transparently and fairly. Also, linkages to performance management, career planning and compensation need to be defined. Logically, engagement will not be impacted by a single training program, regardless of its quality. Enhancing performance is a long-term proposition and requires linkages to the overall personnel and corporate strategies (de Mello 2008). Finally, not all employees respond equally to talent management processes and instruments. Recent research also suggests that personality traits should be included in some of the talent selection processes (Hough, Oswald 2008; Tett, Burnett 2003), and respective tools need to take the personality of employees into account (Fietze, Holst, Tobsch, 2010; Rammstedt 2007).

Therefore, we further expand our performance equation to include a context term which determines how large the impacts of push and pull are:

$\mathrm{P}=\mathrm{f}(\mathrm{A}, \mathrm{M}, \mathrm{O})+\mathrm{c}(\mu-\mathrm{y})$, where c corresponds with elements such a infrastructure and a prosocial orientation enhancing performance outcomes (Lange 1999).

Therefore, in order to support a more pull-oriented culture, a new generation of performance instruments would be required including improved diagnostic powers.

We suggest that the advantage of the pull dynamic is a more efficient process of negotiation between the employee and the organization due to less resistance, resulting in overall higher employee performance. On the other hand, the push dynamic leaves less space for employee creativity and individual contribution. We find that the pull dynamic is 
inherent in all successful talent management instruments and processes. Our results indicate that the instruments and processes with push mechanism are more common in practice, resulting in a lack of alignment between organizational and employee needs and requirements and the under performance of the talent management process in many organizations.

It is important to note that both traditional push or control models and the newer pull models have the same purpose of executing strategy in organizations, just with different means. The equation shows clearly that pull works better, which is supported by the results of this study. However, in the future it will become easier for HR departments to argue for more self-control if cost savings can be proven.

While the pragmatic view of talent management is supported by our findings, it is important to note that a good talent management infrastructure is rarely in place in organizations. If however it is in place, it appears to have a strengthening and positive effect of pull instruments and procedures. However, there appears to be a widespread believe that reductions in people investments are easier to digest for any organization. Overall, talent management programs often do not seem to work the way HR, corporate talent managers and line executives imagine.

\section{Conclusion}

Our findings point at several implications for the practice of talent management. In the area of recruiting, push (topdown) mechanisms are clearly dominating. Yet according to the survey results it remains most efficient when line managers are involved in recruiting and HR only plays a support function. An implication would be that recruiting should be made an integral part of line managers' jobs. However, the results are not surprising, as usually recruiting refers to the external job market and jobs are a scarce good in companies, who therefore need to carefully define their open job profile and put it up for approval before being able to fill the position. Self-control in recruiting also refers to a hiring process described before (Stahl 2007) in which the best talent gets recruited even before a defined job description exists. This process would also work in internal job markets, where self-nomination procedures can actually increase efficiency. In the area of candidate identification, professional headhunting is much more widespread than refer-a-friend programs, in which current employees assume a larger role in the candidate identification process. The table below indicates that the instruments in which current employees can play a significant role are more effective than the elements where this is not the case.

Also in the area of performance management, a classical top-down function executed by supervisors, the instruments with pull mechanism are more successful. In the area of performance management there is again a clear difference in effectiveness among the elements, especially when comparing top-down assessments such as structured assessments with 360 degree feedbacks, which represents a strong pull factor in performance management. Similarly, there is a clear difference in the effectiveness between forced distribution (push) on the one side and recommended distribution of performance indicators on the other.

In this area, the degree to which training is developed, executed and assessed by the employee determines the pull factor. Also, if an employee is lent to a client and he/she has a say in the move, the pull factor is high. The empirical results show that pull-type training is the more effective training.

In addition, an employee portal for training and development on the basis of personalized development plans is more effective than management training (externals).

Compensation management is also still the traditional push retention area. At first sight it seems difficult to implement pull strategies in this area. In the area of compensation, variable salary components are less effective than variable benefits and sabbaticals. In this area, the degree of pull factor is determined by the degree to which compensation decisions are linked to other pull elements in the HR life cycle process, such as in the performance management area, and therefore can be influenced by the employee.

Finally, the results also indicate that personal objectives of the employees must be included in the career planning. In addition, in reality there seems to be doubt that development plans really mirror the career aspirations of the employees, so the implementation of the plans and that they really represent the career aspirations of the employees is very important. Apparently, there are many reasons to believe that this is not the case. So it is required to re-formulate and redesign career plans such that they really represent what individuals wish and want. In this area, mid to long-term succession plans are less effective than personalized career plans.

Overall, the study results may finally lead to an increased use of successful and innovative practices in German organizations, and leading to the use of specific tools and instruments which could be shown to be empirically linked to success.

\section{References}

[1] Aston, C. and Morton, L. (2005), 'Managing Talent for competitive advantage,' Strategic HR Review, 4: 28-31.

[2] Arthur, M. B. (1994) 'The boundaryless career: A new perspective for organizational enquiry,' Journal of Organizational Behaviour, 15, 295-306.

[3] Axelrod, B., Handfield-Jones, H. and Michaels, E. (2002), 'A new game plan for C players,' Harvard Business Review, January, 81-88.

[4] Beechler, S., \& Woodward, I. C. (2009), 'The global war for talent,' in: Journal of International Management, 15 (3), 273-285.

[5] Bernardin, H. J., Cooke, D. K. and Villanova, P. (2000), 'Conscientiousness and agreeableness as predictors of rating leniency,' in: Journal of Applied Psychology, 85, 232-234.

[6] Boselie, P., Dietz, G. and Boon, C. (2005) "Commonalities and contradictions in HRM and performance research", Human Resource Management Journal, 15, 67-94. 
[7] Boxall, P. and Purcell, J. (2008), 'Strategy and Human Resource Management', $2^{\text {nd }}$ Edition, Basingstoke and New York: Palgrave Macmillan.

[8] Busck, Ole, Knudsen, Herman, Lind, Jens (2010), 'The transformation of employee participation: Consequences for the work environment,' in Economic \& Industrial Democracy, August 2010, Vol. 31 Issue 3, 284-305, 21p.

[9] Cappelli, P. (2008), 'Talent Management for the Twenty-First Century,' in Harvard Business Review, March 2008, 74-81.

[10] Clutterbuck, D. (2010), 'Talent and succession planning,' in HR Vision, January 2010.

[11] Collings, D. G. and Mellahi, K. (2009), 'Strategic Talent Management: A review and research agenda,' in: Human Resource Management Review, 19: 4, 304-313.

[12] De Mello, Cristina; Wildermuth, Souza; Pauken, Patrick David (2008), 'A perfect match: decoding employee engagement - Part II: engaging jobs and individuals,' in Industrial \& Commercial Training; 2008, Vol. 40 Issue 4, 206-210, 5p.

[13] Deloitte Human Capital Trends Study 2015.

[14] Fietze, S., Holst E., \& Tobsch, V. (2010). ,Germany's Next Top Manager: Does Personality explain the Gender Career Gap?' Joint Research and Discussion Paper No. 3., International Institute of Management, University of Flensburg and Department of Border Region Studies, University of Southern Denmark, Flensburg/Sonderburg.

[15] Germain, J. (2010), 'How to DRIVE your Troublesome Talent forward to success,' in Manager: British Journal of Administrative Management, Spring 2010, Issue 70, p18-19, 2p.

[16] Groysberg, B., Nanda, A., Nohria, N. (2004), 'The risky business of hiring stars.' in Harvard Business Review 1-10 (May 1).

[17] Groysberg, B., McLean, A., Nohria, N. (2006), 'Are leaders portable?' in Harvard Business Review 1-10 (May 1).

[18] Groysberg, B., McLean, A., Nohria, N. (2008), 'How star women build portable skills' in Harvard Business Review 1-8 (February).

[19] Hough, L. M., \& Oswald, F. L. (2008), 'Personality testing and I-O psychology: Asking questions, offering answers, discussing unknowns, and providing direction,' in: Industrial and Organizational Psychology, 1 (3).

[20] Knoblauch, J. (2010), 'Die Personalfalle. Schwaches Personalmanagement ruiniert Unternehmen,' Campus 2010.

[21] Lewis, R. E., \& R. J. Heckman (2006), 'Talent management: A critical review,' in Human Resource Management Review, 16: 139-154.

[22] Martin, J. and Schmidt, C. (2010), 'How to Keep Your Top Talent,' in Harvard Business Review; May 2010.

[23] Meifert, M. T., (eds.) (2010), 'Strategische Personalentwicklung. Ein Programm in acht Etappen,' Springer 2010.
[24] Michaels, E., Handfield-Jones, H. and Axelrod, B. (2001), 'The War for Talent', Boston, Harvard Business School Press.

[25] Moser, R., Saxer, A. (2008), 'Retention Management für High Potentials, Konzeptionelle Grundlagen-empirische Ergebnisse-Gestaltungsempfehlungen,' Vdm Verlag Dr. Müller 2008.

[26] Pfeffer, J (2001). 'Fighting the War for Talent is Hazardous to Your Organization's Health.' Organizational Dynamics, 29 (4), 248-259.

[27] Pfeffer, Jeffrey and Robert I. Sutton (2006) 'Evidence-Based Management' in Harvard Business Review, 84 (1), 2006, 6374.

[28] Rammstedt, B. (2007), 'Who worries and who is happy? Explaining individual differences in worries and satisfaction by personality.' in: Personality and Individual Differences, 43, 1626-1634.

[29] Rousseau (1762), 'Du contrat social; ou, principes du droit politique.' Amsterdam.

[30] Sliwka (2008), 'Transparency, Inequity Aversion, and the Dynamics of Peer Pressure in Teams: Theory and Evidence,' in: Journal of Labor Economics 26 (2008), 693-720.

[31] Stage \& Houghton (2009), 'IMI's Aspire program feeds its senior leader pipeline through self nominations,' in Wiley Interscience, July/August 2009.

[32] Stage, Victoria, Houghton, Russell (2009), 'IMI's Aspire program feeds its senior leader pipeline through selfnominations,' in Global Business \& Organizational Excellence, Jul/Aug 2009, Vol. 28 Issue 5, 16-25.

[33] Stahl, G. K., Bjorkman, I., Farndale, E., Morris, S. S., Stiles, P., Trevor, J. \& Wright, P. M. (2007), 'Global Talent Management: How Leading Multinationals Build and Sustain Their Talent Pipeline,' Faculty \& Research Working Paper. Fontainebleau, France, INSEAD.

[34] Tarique \& Schuler (2009), 'Global talent management: Literature review, integrative framework, and suggestions for further research,' in Journal of World Business, April 2010, Vol. 45 Issue 2, 122-133.

[35] Tett, R. P., \& Burnett, D. D. (2003). 'A personality trait-based interactionist model of job performance.' Journal of Applied Psychology, 88, 500-517.

[36] Theorell, T., Karasek, R. A., (1990). 'Healthy Work. Stress, Productivity and the reconstruction of working life.' Basic Books, New York.

[37] Ulrich, D., Strategic personnel management, 2007.

[38] Van Nuland \& Hanke, 'Exploring the motivation jungle: Predicting performance on a novel task by investigating constructs from different motivation perspectives in tandem,' in International Journal of Psychology; August 2010, Vol. 45 Issue 4, 250-259.

[39] Walton, R. E., From Control to Commitment in the workplace. 